\title{
Graphene oxide enhances $\beta$-amyloid clearance by inducing autophagy of microglia and neurons
}

\author{
Xiaolin $\mathrm{Li}^{1}$, Kai $\mathrm{Li}^{1}$, Fangxuan $\mathrm{Chu}^{1}$, Jie Huang ${ }^{2}$, Zhuo Yang ${ }^{1 *}$ \\ ${ }^{1}$ Medical School, State Key Laboratory of Medicinal Chemical Biology, Key Laboratory of \\ Bioactive Materials for Ministry of Education, Nankai University, Tianjin 300071, China \\ ${ }^{2}$ Department of Mechanical Engineering, University College London, London, UK \\ $1 *$ Corresponding author:
}

Professor YANG Zhuo, College of Medicine, Nankai University, Tianjin 300071, China

Tel: $86-22-23504364$

Fax: 86-22-23502554

Email: zhuoyang@,nankai.edu.cn

Graphical abstract

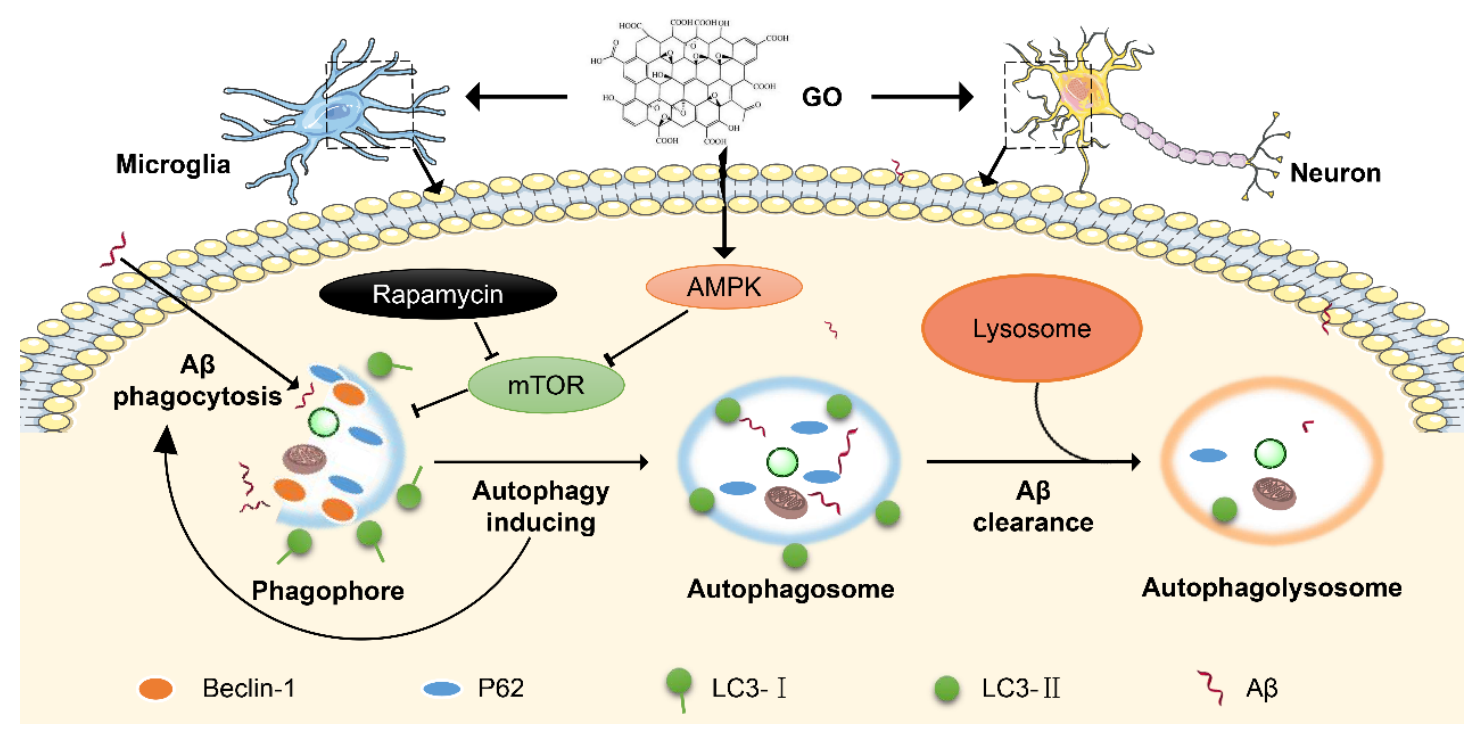




\title{
Highlights
}

- Graphene oxide (GO) protected neurons in pathological conditions.

- Microglia and neurons were co-cultured to simulate pathological environment.

- GO promoted the clearance of $A \beta$ in pathological conditions.

- GO induced autophagy of microglia and neurons through the AMPK / mTOR pathway.

\begin{abstract}
Alzheimer's disease (AD) is a common neurodegenerative disease, and its pathogenesis is closely related to $\beta$-amyloid $(A \beta)$ peptide. The deposition of $A \beta$ in the brain due to impaired $A \beta$ clearance is considered as an important cause of $\mathrm{AD}$. The decrease in $A \beta$ clearance is closely related to the autophagy dysfunction in brains of $\mathrm{AD}$ patients. It is feasible to treat $\mathrm{AD}$ by increasing the autophagy level of cells such as microglia and neurons to accelerate $A \beta$ clearance. In this article we explored the ability of graphene oxide (GO) to clear $A \beta$ through activating autophagy. Our work demonstrated that GO could inhibit the mTOR signaling pathway by activating AMPK to induce the autophagy of microglial and neurons. As expected, with the improvement of autophagy ability of microglia, GO promoted microglia-mediated A $\beta$ phagocytosis. Under the conditions of co-culture of microglia and neurons, GO induced the autophagy of microglia and neurons, especially the autophagy of microglia, thereby promoting the clearance of $A \beta$, and ultimately achieved the effect of protecting neurons. Moreover,
\end{abstract}


GO was not only non-cytotoxic to microglia and neurons but also able to reduce the toxicity of $A \beta$ to neurons through its clearance. These results have shown the potential of GO in treating Alzheimer's disease.

Keywords: Graphene oxide, Alzheimer's disease, $\beta$-amyloid clearance, autophagy, coculture, mTOR

Abbreviations: AD, Alzheimer's disease; $A \beta, \beta$-amyloid; GO, graphene oxide; mTOR, mammalian targets of rapamycin; AMPK, AMP-activated protein kinase; TLRs, Talllike receptors; $\mathrm{BBB}$, blood-brain barrier; $\mathrm{BCSFB}$, blood-cerebral spinal fluid barrier; Beclin-1, autophagy inducer Beclin-1; LC3, microtuble-associated protein 1 light chain 3; P62, autophagy adaptor p62; NF-кB, nuclear factor-kappa B; 3-MA, 3methyladenine; Rapa, rapamycin; FBS, fetal bovine serum; AO, acridine orange; RA, retinoic acid; TEM, Transmission electron microscopy; PBS, phosphate-buffered saline; CLSM, Confocal laser scanning microscope; NGS. normal goat serum.

\section{Introduction}

Alzheimer's disease (AD) occurs mostly in the elderly, with a slow and irreversible course. The main pathological hallmarks of AD include the excessive deposition of $\beta$ amyloid $(\mathrm{A} \beta)$ peptide in brain parenchymal and the hyperphosphorylated tau protein to form neurofibrillary tangles intraneuronal, resulting in neuronal death $[1,2]$. The amyloid cascade hypothesis suggests that $A \beta$ protein accumulation in the brain is the underlying cause of $\mathrm{AD}[3]$. A $\beta$ protein causes neuronal apoptosis in many ways [4-6]. Therefore, reducing the accumulation of $A \beta$ has been the focus of many studies aimed at the prevention and treatment of AD [7]. Many studies have shown that the decreased 
$A \beta$ clearance is the main cause of $A \beta$ deposition [8]. The deposition of $A \beta$ is mainly caused by decreased clearance of $A \beta$ rather than increased production of $A \beta$ [9]. Some candidate drugs, such as solanezumab monoclonal antibodies that are selectively targets $A \beta$ protein, have been designed to clear $A \beta$ by combining soluble $A \beta$ proteins in blood and brain $[10,11]$. Therefore, to remove the clearance obstacle is one of the key treatment strategies in reducing brain parenchymal levels of $\mathrm{A} \beta$ and improving cognitive impairment in most $\mathrm{AD}$ cases.

There are many ways to clear $A \beta$, including the efflux of the blood-brain barrier (BBB) and the blood-cerebral spinal fluid barrier (BCSFB), enzymatic degradation clearance and cell autophagy degradation clearance [12-14], particularly, the autophagy degradation of microglia and neurons in the brain $[15,16]$. Studies have shown that the dysfunction of the autophagy-lysosomal system severely impedes the ability of cells to clear $\mathrm{A} \beta$ and then increases the harmful $\mathrm{A} \beta$ in the brain of $\mathrm{AD}$ patients $[14,17,18]$. Accelerating the $A \beta$ clearance by increasing autophagy is a promising approach. The process of autophagy is regulated by many signaling molecules, such as mammalian targets of rapamycin (mTOR), AMP-activated protein kinase (AMPK), Tall-like receptors (TLRs), and so on $[19,20]$. In addition, many autophagy-related proteins are involved in the process of autophagy. For example, the autophagy inducer Beclin-1 (Beclin-1), microtuble-associated protein 1 light chain 3 (LC3) and autophagy adaptor p62 (P62) [21-23]. The changes of these autophagy-related proteins reflect the changes of autophagy levels in brain cells of $\mathrm{AD}$ patients. In the brains of $\mathrm{AD}$ patients, defects in the autophagy of microglia and neurons severely hinder $A \beta$ clearance [14]. If the 
autophagy ability of microglia and neurons can be increased at the same time, the elimination of $\mathrm{A} \beta$ will be accelerated.

Carbon-based nanomaterials displayed a variety of functions, directly regulate the physiological behavior of cells because of unique structure and biological properties [24-26]. Graphene oxide (GO), as a derivative of graphene, has abundant hydrophilic groups (carboxyl, hydroxyl and epoxy groups) and a high stability in aqueous dispersions compared to the original graphene [27]. GO has been studied in the induction of pluripotent stem cell culture [28], cell growth [29] and drug delivery [30]. Recent studies have found that GO induces autophagy in a variety of cells including RAW264.7 macrophages, CT26 colon cancer cells, and so on [31, 32]. Graphenederived nanomaterial-induced autophagy involves some signaling pathways. For example, the nuclear factor-kappa B (NF- $\kappa \mathrm{B})$ and mTOR pathways are involved in graphene quantum dots (GQD) -induced autophagy [33, 34]. The activation or inhibition of the mTOR pathway has been studied in other diseases and nanomaterials $[20,35,36]$, and it may also play an important role in GO-induced autophagy.

Therefore, we aim to explore the ability of GO to clear A $\beta$ by inducing autophagy in microglia and neurons and assess the potential of GO for treating $\mathrm{AD}$ and other neurodegenerative diseases. We tested whether GO can increase the autophagy levels of microglia and neurons, and explored the mechanism of autophagy induction. The microglia and neurons were co-cultured to simulate the more realistic AD pathological environment, and to evaluate the ability of GO to increase the clearance of $\mathrm{A} \beta$ by inducing autophagy and protect neurons. 


\section{Materials and methods}

\subsection{Materials}

GO was purchased from Jiangsu XFNANO Materials Tech. Co., Ltd. DMEM cell culture medium and trypsin were purchased from GIBCO Invitrogen. 3-methyladenine (3-MA), rapamycin (Rapa), fetal bovine serum (FBS), and acridine orange (AO) were purchased from Sigma. Compound C is from Selleck, USA. Anti-AMPK antibody, antiphospho AMPK antibody, anti-mTOR antibody, anti-phospho mTOR antibody and anti-LC3 antibody were purchased from Cell Signaling Technology, USA. AntiSQSTM1/p62 antibody was purchased from Abcam, UK. Anti-Beclin-1 antibodies were purchased from Wanleibio.

\subsection{Preparation of small sheet diameter GO}

The original sheet diameter of GO was $500 \mathrm{~nm}-5 \mu \mathrm{m}$, and the thickness was 0.8 $1.2 \mathrm{~nm} .1 \mathrm{mg}$ of GO powder was accurately weighed with an electronic balance and placed on a sterile bench for 30 min under ultraviolet irradiation, and then carefully added to $1 \mathrm{ml}$ of sterile deionized water to prepare GO mother liquor. The prepared mother liquor was put into an ultrasonic instrument with a power of $500 \mathrm{~W}$ and sonicate for $48 \mathrm{~h}$ under the condition that the water temperature was lower than $37{ }^{\circ} \mathrm{C}$. After sonication, the large-sized GO was broken into a small-sized GO having a diameter less than $50 \mathrm{~nm}$, and then stored at $4{ }^{\circ} \mathrm{C}$ in the dark for subsequent testing.

\subsection{Cell culture}

Mouse BV2 microglial cells and human SH-SY5Y neuroblastoma cells were cultured in DMEM high glucose medium supplemented with 10\% FBS and 1\% 
penicillin/streptomycin at $37{ }^{\circ} \mathrm{C}$ in the $95 \%$ humidified atmosphere with $5 \% \mathrm{CO} 2$. The SH-SY5Y cells were cultured in medium containing retinoic acid (RA, $10 \mu \mathrm{M}$ ) for 1 week to induce cell differentiation [37]. The medium was changed every 2 days and the cells was passaged in time according to the growth density of the cells.

\subsection{Co-culture}

BV2 cells and SH-SY5Y cells were cultured in petri dishes containing sterile cover slips in preparation for co-culture. When the cells adhered and grown well, one cover slip of BV2 cells and one cover slip of SH-SY5Y cells were placed in one 60-mm dish and co-cultured in culture medium [38]. One day later, co-cultured cells were subjected to further experiments described in the following.

\subsection{Transmission electron microscopy (TEM)}

The morphology and size of GO were observed by TEM. GO was dissolved in sterile water to prepare GO solutions of different concentrations $(0.3 \mu \mathrm{g} / \mathrm{ml}, 0.06 \mu \mathrm{g} / \mathrm{ml}$, $0.006 \mu \mathrm{g} / \mathrm{ml}$ ) according to the requirements of TEM photography. The GO solutions were obtained after ultrasound treatment for $48 \mathrm{~h}$ below $37^{\circ} \mathrm{C} .10 \mu \mathrm{GO}$ solutions were dropped onto a copper mesh for $5 \mathrm{~min}$, and then most of the liquid was removed with a filter paper. After the copper mesh was dried, the shape and size of GO were photographed.

\subsection{Cell viability assay (MTT)}

The effects of GO on the cell viability of microglia and neurons were assessed by the MTT assay. BV2 cells and SH-SY5Y cells were seeded in 96-well plates with $1 \times$ $10^{4}$ cells in $100 \mu \mathrm{l}$ medium per well and then cultured $12 \mathrm{~h}$ for the stabilization. Then, 
$100 \mu \mathrm{l}$ of the medium containing different concentrations of GO $(12.5 \mu \mathrm{g} / \mathrm{ml}, 25 \mu \mathrm{g} / \mathrm{ml}$, $50 \mu \mathrm{g} / \mathrm{ml}, 100 \mu \mathrm{g} / \mathrm{ml}, 200 \mu \mathrm{g} / \mathrm{ml}$ ) was added to each well. After $24 \mathrm{~h}$ of treatment with $\mathrm{GO}, 20 \mu \mathrm{l}$ of MTT $(5 \mathrm{mg} / \mathrm{ml})$ was added to each well and treated for $4 \mathrm{~h}$ at $37{ }^{\circ} \mathrm{C}$. The medium was then replaced with $150 \mu \mathrm{DMSO}$ and the absorbance was measured at a wavelength of $492 \mathrm{~nm}$ [36]. Each group was provided with six parallel wells, and the experiments were performed six times.

\subsection{Western blot assay}

The cells were cultured in 6-well plates and treated with four different conditions including phosphate-buffered saline (PBS), $50 \mu \mathrm{g} / \mathrm{ml} \mathrm{GO}, 100 \mu \mathrm{g} / \mathrm{ml}$ GO and rapamycin Rapa for $24 \mathrm{~h}$. After that, the cells were washed with PBS and the RIPA lysate (1\% PMSF) was added lysing on ice for $15 \mathrm{~min}$. Then the lysates were harvested and centrifuged at $11000 \mathrm{~g}$ for $15 \mathrm{~min}$ at $4{ }^{\circ} \mathrm{C}$. The protein concentrations in supernatant were measured using the BCA protein assay kit. The supernatant was separated, mixed with $4 \mathrm{X}$ loading buffer, and placed in metal bath at $100{ }^{\circ} \mathrm{C}$ for $15 \mathrm{~min}$. Equal amounts of total proteins extracts $(30 \mu \mathrm{g})$ were run on a $10-13 \%$ SDS-PAGE gel and transferred to a PVDF membrane at $100 \mathrm{~V}$ for $100 \mathrm{~min}$. Then the PVDF membrane was blocked with $5 \%$ fat-free milk powder for $1 \mathrm{~h}$ at room temperature. After that, the PVDF membranes were incubated with primary antibodies overnight at $4{ }^{\circ} \mathrm{C}$, and then washed with TBST for $4 \times 10 \mathrm{~min}$. Then the PVDF membranes were incubated with the secondary antibody for $1 \mathrm{~h}$ and washed $4 \times 10 \mathrm{~min}$ with TBST. Finally, the PVDF membrane was placed in an exposure apparatus for imaging [39].

\subsection{Acridine orange stain}


Acridine orange (AO) is a fluorescent dye, which can stain acidic autophagosomes or acid lysosomes in cells to orange or red and other parts (such as cytoplasm and nucleus) to green. The cells were cultured on coverslips and treated with different conditions (PBS, $50 \mu \mathrm{g} / \mathrm{ml} \mathrm{GO}, 100 \mu \mathrm{g} / \mathrm{ml} \mathrm{GO}$, Rapa) for $24 \mathrm{~h}$. Then the cells were washed with PBS and stained with $1 \mu \mathrm{M}$ acridine orange for $15 \mathrm{~min}$ at $37^{\circ} \mathrm{C}$. After that, the excess acridine orange was washed out by PBS. The cells were immediately analyzed under a fluorescence microscope [40]. All experiments were repeated at least for three times.

\subsection{Confocal laser scanning microscope (CLSM) observation}

The difference in A $\beta$ phagocytosis ability of cells incubated with or without GO was investigated by confocal laser scanning microscopy. The cells were seeded in complete DMEM medium, at a humidified atmosphere of $5 \% \mathrm{CO}_{2}$, and cultured at $37{ }^{\circ} \mathrm{C}$ overnight. Then, the culture medium was replaced with a serum-free fresh medium containing PBS, $50 \mu \mathrm{g} / \mathrm{ml} \mathrm{GO}, 100 \mu \mathrm{g} / \mathrm{ml} \mathrm{GO}$, and Rapa respectively and FITC-labeled $A \beta(2.5 \mu \mathrm{M})$. Afterwards, the cells were cultured with the fresh serumfree medium for $3 \mathrm{~h}$, and washed 3 times with PBS. Finally, the cells were imaged using a confocal laser scanning microscope [41].

\subsection{Flow cytometry}

The cells were seeded into the 12-well plate and cultured in a humidified atmosphere with $5 \% \mathrm{CO}_{2}$ at $37{ }^{\circ} \mathrm{C}$ overnight. After reaching a confluency, the cells were washed with PBS, and cultured in serum-free medium containing PBS, $50 \mu \mathrm{g} / \mathrm{ml} \mathrm{GO}$, $100 \mu \mathrm{g} / \mathrm{ml}$ and Rapa respectively. At the same time, the A $\beta$-FITC $(2.5 \mu \mathrm{M})$ was added to each well and were co-incubated with the cells for $3 \mathrm{~h}$. After washing with PBS 3 
times, the $4 \%$ paraformaldehyde $(400 \mu \mathrm{l})$ was added to each well, and the adherent cells were processed into suspension cells quickly with the pipette. The cell suspension was then transferred to $1.5 \mathrm{ml}$ centrifuge tube. Finally, the average fluorescence intensity of the cells was measured in a flow cytometer [42].

\subsection{Immunofluorescence}

The cells were seeded on sterile coverslips in 6-well plates, and cultured in the media containing PBS, $50 \mu \mathrm{g} / \mathrm{ml} \mathrm{GO}, 100 \mu \mathrm{g} / \mathrm{ml} \mathrm{GO}$ and Rapa respectively for $12 \mathrm{~h}$. Then the cells were washed 3 times with PBS, and exposed to 4\% paraformaldehyde for $10 \mathrm{~min}$. After that, the cells were washed in PBS for $3 \times 10 \mathrm{~min}$, and the $0.5 \%$ Triton X-100 for $10 \mathrm{~min}$. The cells were washed with PBS $(3 \times 10 \mathrm{~min})$ and blocked with $10 \%$ normal goat serum (NGS) for $1 \mathrm{~h}$ at room temperature. Then the cells were incubated with the primary antibody at $4{ }^{\circ} \mathrm{C}$. After 12 hours, the cells were washed with PBS, and incubated with the fluorescent secondary antibody for one hour in dark conditions. After washing with PBS, the cells were stained with DAPI for 5 min and imaged under a fluorescence microscope [39].

\subsection{Statistical analyses}

All data analysis used SPASS 22 software, and the experimental data were presented using mean \pm standard error (S.E.M). The data between multiple samples were analyzed by one-way ANOVA (one-way ANOVA), and LSD analysis was used to make multiple comparisons after the fact. The significance level was set to $\mathrm{P}<0.05$, which signified a significant difference. $\mathrm{P}<0.01$ represented a very significant difference in comparison. 


\section{Results}

\subsection{Graphene oxide had no cytotoxicity to microglia and neurons}

The small-sized GO was obtained by sonicating the large-sized GO for $48 \mathrm{~h}$. The ultrasonic-treated GO observed by TEM was shown in Fig. 1a, and GO exhibited a single-layer nanosheets shape. The average length of nanoflake was estimated by measuring more than 200 nanosheets in the TEM image. The results showed that the GO nanoflake size ranged from $10 \mathrm{~nm}$ to $80 \mathrm{~nm}$. As shown in Fig. $1 \mathrm{~b}$, the size distribution of the GO nanoflake indicated that $90 \%$ was less than $40 \mathrm{~nm}$ and $99 \%$ was less than $60 \mathrm{~nm}$.

The effects of GO on the viability of microglia and neurons were determined by the MTT assay. The BV2 cells and SH-SY5Y cells were treated with GO at different concentrations $(0,12.5,25,50,100,200 \mu \mathrm{g} / \mathrm{ml})$ for 24 hours. As shown in Fig. 1c-d, the cell viability of BV2 cells and SH-SY5Y cells did not change significantly with the increasing of GO concentration. 
a
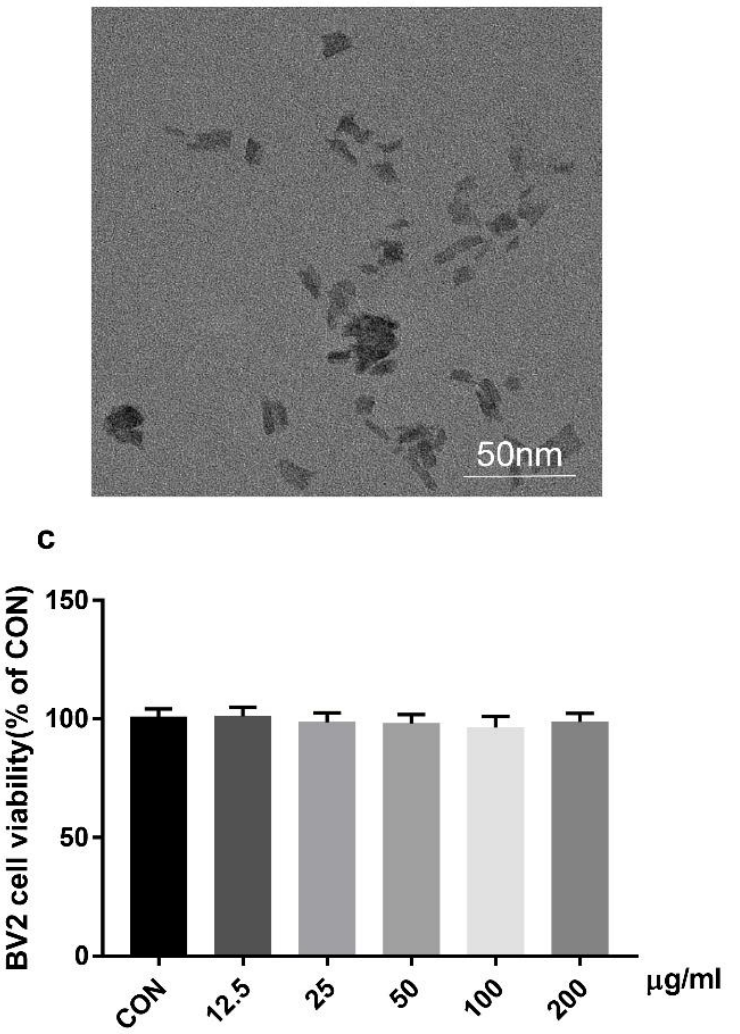

b

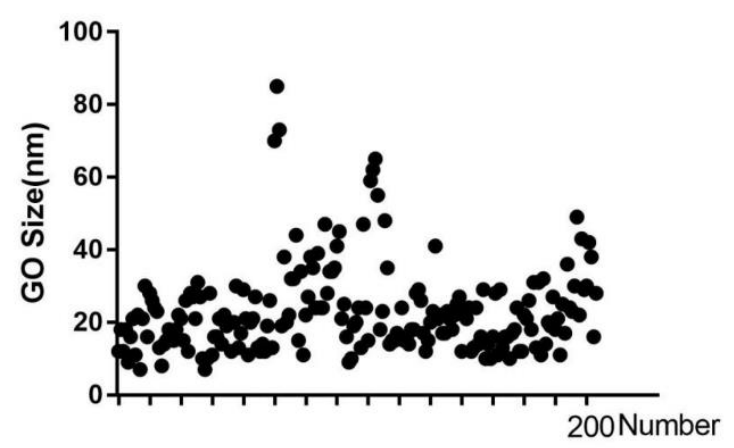

d

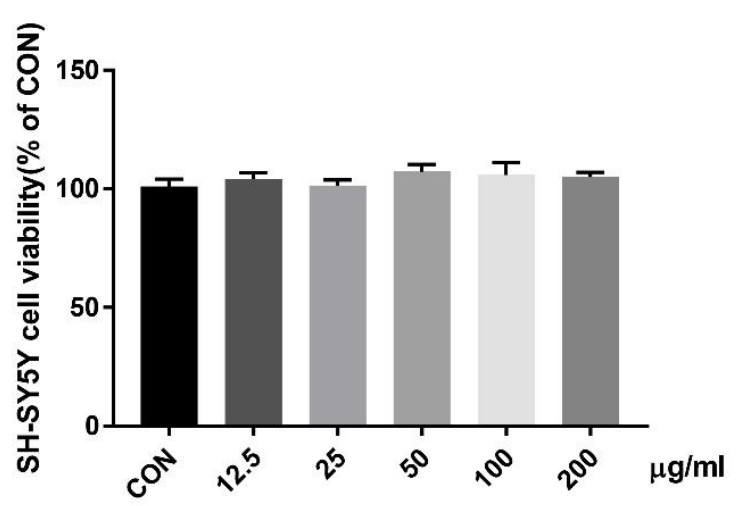

Figure 1. The Morphological dimensions and cytotoxicity of GO. (a) The morphology and size of GO measured by TEM (scale bar: 50nm). (b) The size distribution of GO flakes ( $>200$ ) measured from Image J. The average GO length was found to be 10 to $40 \mathrm{~nm}$. (c) The viability of BV2 cells after $24 \mathrm{~h}$ co-incubation with GO nanoflakes measured from MTT assay. BV2 cells were treated with $0(\mathrm{CON}), 12.5$, $25,50,100$, and $200 \mu \mathrm{g} / \mathrm{ml}$ of GO. The data represent mean \pm standard deviation (S.E.M) of six independent culture experiments. (d) The viability of SH-SY5Y cells after $24 \mathrm{~h}$ co-incubation with GO nanoflakes measured from MTT assay. SH-SY5Y cells were treated with $0(\mathrm{CON}), 12.5,25,50,100$, and $200 \mu \mathrm{g} / \mathrm{ml}$ of GO. The data represent mean \pm standard deviation (S.E.M) of six independent culture experiments. 


\subsection{Graphene oxide activated the autophagy in microglia and neurons}

The changes of autophagy-related proteins in the BV2 cells and SH-SY5Y cells were determined whether GO can induce autophagy in microglia and neurons. Firstly, a GO-induced autophagy in the BV2 cells was found in a dose-dependent manner when the cells were treated with different concentrations of GO. As shown in Fig. 2a-c, the expression of beclin-1 was significantly increased especially at the GO concentration of $100 \mu \mathrm{g} / \mathrm{ml}$. While the content of P62 was remarkably decreased at the $100 \mu \mathrm{g} / \mathrm{ml} \mathrm{GO}$. Therefore, the concentration of $100 \mu \mathrm{g} / \mathrm{ml} \mathrm{GO}$ was selected for the following experiments and set three groups including control, $50 \mu \mathrm{g} / \mathrm{ml} \mathrm{GO}$, and autophagy activator rapamycin to contrast with the group of $100 \mu \mathrm{g} / \mathrm{ml} \mathrm{GO}$. Secondly, we tested the changes of three autophagy-related proteins (LC3, Beclin-1 and SQSTM1/p62) after treating the BV2 cells and SH-SY5Y cells by the four conditions (control, 50 $\mu \mathrm{g} / \mathrm{ml} \mathrm{GO}, 100 \mu \mathrm{g} / \mathrm{ml} \mathrm{GO}$ and Rapa) for $24 \mathrm{~h}$. The results for the BV2 cells were shown in Fig. 2d-g. Compared with the control group and $50 \mu \mathrm{g} / \mathrm{ml} \mathrm{GO}$ group, the expression of Beclin-1 was significantly increased at the $100 \mu \mathrm{g} / \mathrm{ml} \mathrm{GO}$ group and even higher than the Rapa group. At the same time, the expression of P62 was significantly decreased at the $100 \mu \mathrm{g} / \mathrm{ml} \mathrm{GO}$ group, and the expression of LC3-II/LC3-I was significantly increased at the $100 \mu \mathrm{g} / \mathrm{ml}$ GO group. As shown in Fig.3a-d, similar results were obtained in the SH-SY5Y cells. After treatment with $100 \mu \mathrm{g} / \mathrm{ml} \mathrm{GO}$, Beclin-1 content was increased even more than the Rapa group, while the reduction of P62 was also observed. Moreover, the ratio of LC3-II/LC3-1 was also significantly increased. 
a

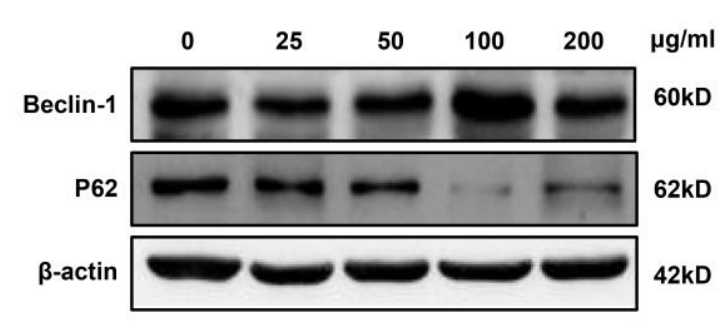

C

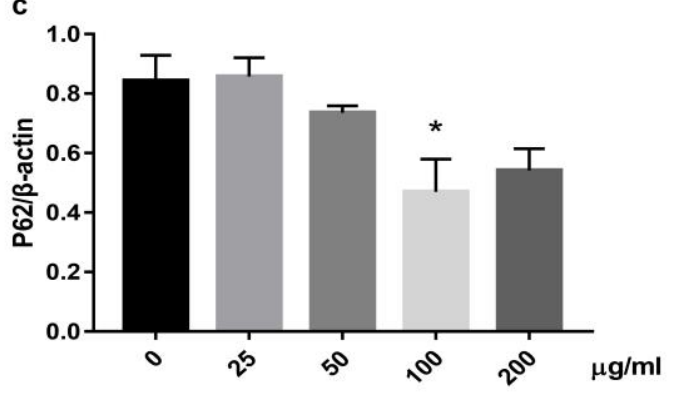

e

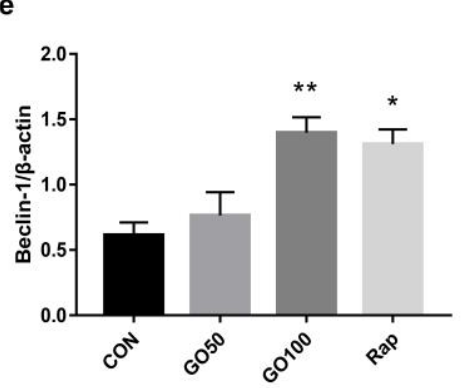

b

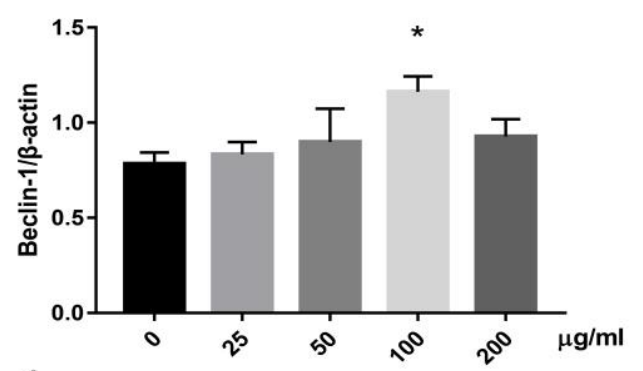

d

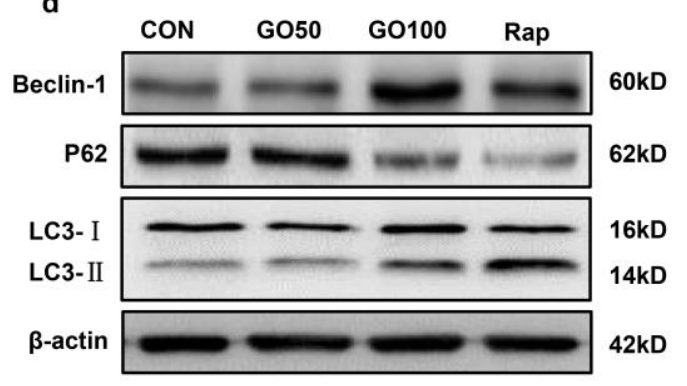

g
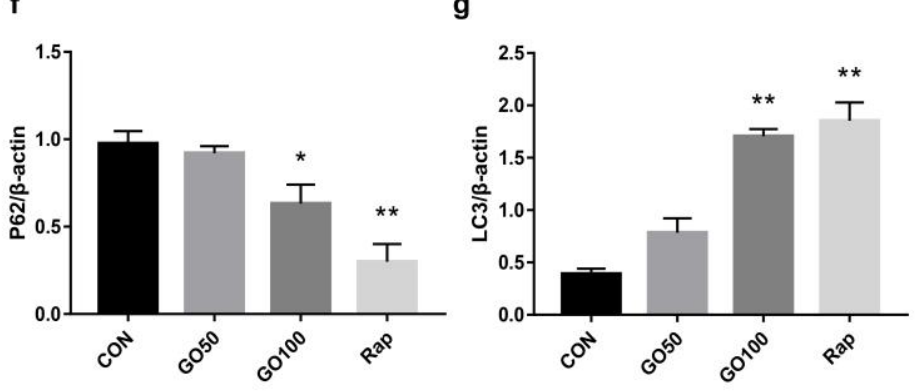

Figure 2. GO-induced autophagy flux in BV2 cells. (a) The representative immunoreactive bands of Beclin1 (60 kD), p62 (62 kD), and $\beta$-actin (42kD). BV2 cells were treated for $24 \mathrm{~h}$ with $0 \mu \mathrm{g} / \mathrm{ml} \mathrm{GO}, 25 \mu \mathrm{g} / \mathrm{ml} \mathrm{GO}, 50 \mu \mathrm{g} / \mathrm{ml} \mathrm{GO}, 100 \mu \mathrm{g} / \mathrm{ml} \mathrm{GO}$ and $200 \mu \mathrm{g} / \mathrm{ml} \mathrm{GO}$. (b) Quantitative analysis of Beclin-1/ $\beta$-actin in five groups. $\mathrm{n}=3$ /group, * $\mathrm{P}<0.05$ vs. $0 \mu \mathrm{g} / \mathrm{ml} \mathrm{GO}$ group. (c) Quantitative analysis of $\mathrm{P} 62 / \beta$-actin in five groups. $\mathrm{n}=3$ /group, $* \mathrm{P}<0.05$ vs. $0 \mu \mathrm{g} / \mathrm{ml} \mathrm{GO}$ group. (d) The representative immunoreactive bands of Beclin1 (60 kD), p62 (62 kD), LC3-I (16 kD), LC3-II (14 kD), and $\beta$-actin (42 kD). BV2 cells were treated for $24 \mathrm{~h}$ with PBS (CON), $50 \mu \mathrm{g} / \mathrm{ml} \mathrm{GO}(\mathrm{GO} 50), 100$ $\mu \mathrm{g} / \mathrm{ml} \mathrm{GO}$ (GO100) and rapamycin (Rap). (e) Quantitative analysis of Beclin-1/ $\beta$-actin in four groups. $\mathrm{n}=3$ /group, $* \mathrm{P}<0.05, * * \mathrm{P}<0.01$ vs. CON group. (f) Quantitative 
analysis of $\mathrm{P} 62 / \beta$-actin in four groups $\mathrm{n}=3$ /group, ${ }^{*} \mathrm{P}<0.05$, $* * \mathrm{P}<0.01$ vs. CON group. (g) Quantitative analysis of LC3-II/LC3-I in four groups. $\mathrm{n}=3$ /group, ${ }^{* *} \mathrm{P}<0.01$ vs. CON group.

The degradation of $\mathrm{A} \beta$ occurred through the autophagy-lysosomal system in cells, so acridine orange staining was performed to detect the accumulation of acid lysosomes in the cells. As shown in Fig. 3e, the results were similar in the BV2 cells and SH-SY5Y cells. The cells showed green fluorescence with minimum orange or red fluorescence in the control group, which suggested a lack of acidic autophagic vesicles. The orange or red fluorescence was significantly increased in the $50 \mu \mathrm{g} / \mathrm{ml} \mathrm{GO}$ group compared that in the control group. As expected, the $100 \mu \mathrm{g} / \mathrm{ml} \mathrm{GO}$ group and the Rapa group showed more pronounced orange or red fluorescence than those of the $50 \mu \mathrm{g} / \mathrm{ml} \mathrm{GO}$ group. The results from the AO assay were consistent with the results of Western blotting assay.

\subsection{Graphene oxide promoted microglia-mediated phagocytosis of Aß}

Since an increase in the autophagy capacity of microglial cells could induce the microglia to phagocytose [43], the ability of microglia to phagocytize $\mathrm{A} \beta$ was tested. After being incubated with $2.5 \mu \mathrm{M}$ FTTC-labeled A $\beta$ for 3 hours, the BV2 cells in four groups (control, $50 \mu \mathrm{g} / \mathrm{ml} \mathrm{GO}, 100 \mu \mathrm{g} / \mathrm{ml} \mathrm{GO}$ and Rapa) were examined using a confocal microscope. As shown in Fig. 3f, the green fluorescence was significantly increased in the BV2 cells in the $50 \mu \mathrm{g} / \mathrm{ml} \mathrm{GO}$ group compared with the control group, 
and further increases were observed in the $100 \mu \mathrm{g} / \mathrm{ml} \mathrm{GO}$ group and the Rapa group. The intracellular $A \beta$ fluorescence intensity was further quantified by flow cytometry. As shown in Fig. $3 \mathrm{~g}$, the average fluorescence intensity was significantly increased in the GO-treated cells, and the fluorescence intensity increased significantly in the 100 $\mu \mathrm{g} / \mathrm{ml} \mathrm{GO}$ group and almost comparable to the fluorescence intensity of the Rapa group. The statistic results from flow cytometry were consistent with the examination under confocal microscopy. 
a
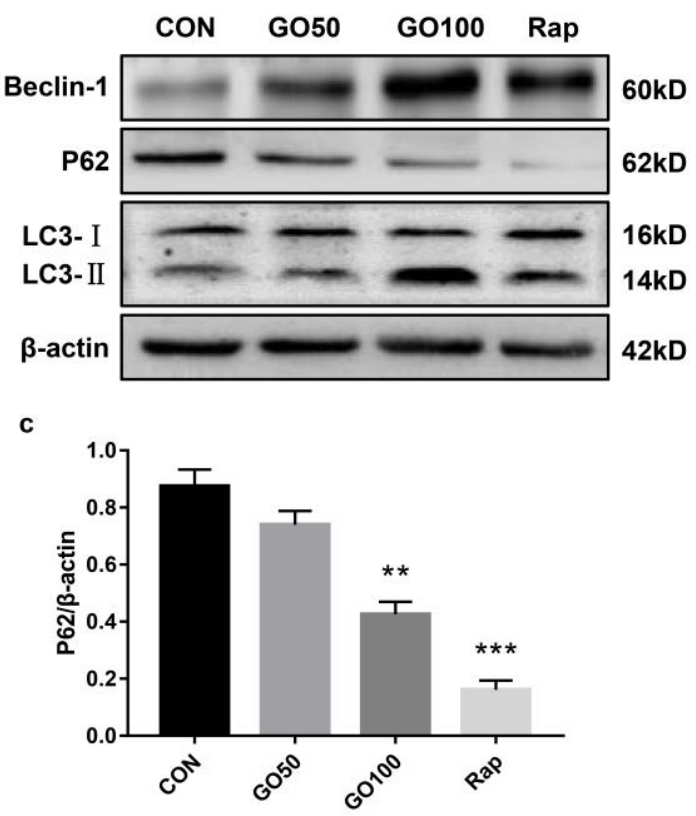

e
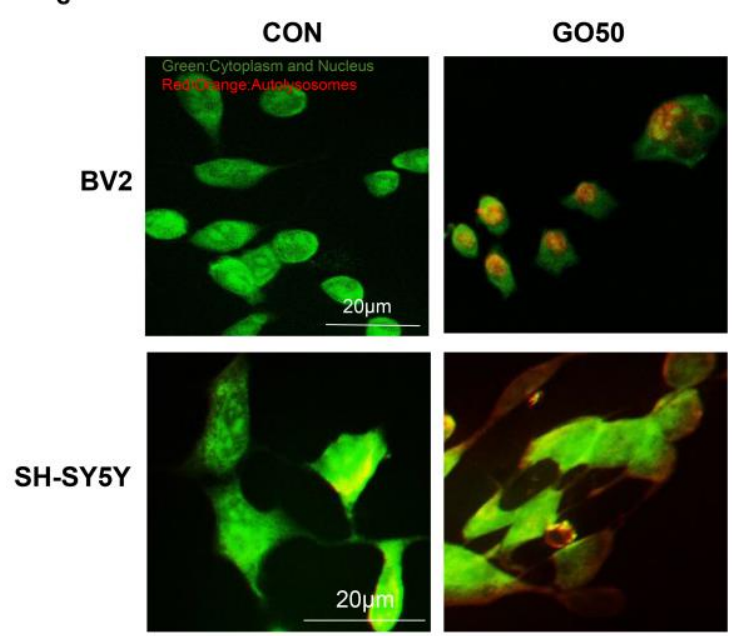

$$
\text { f }
$$
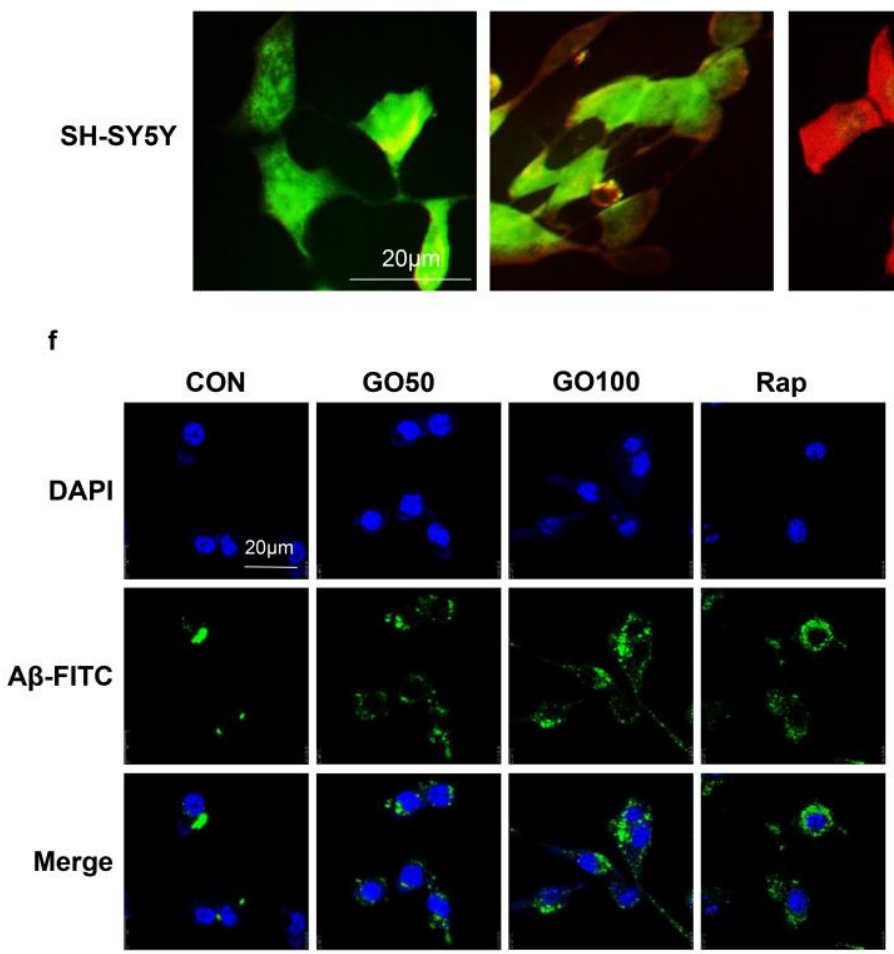

g
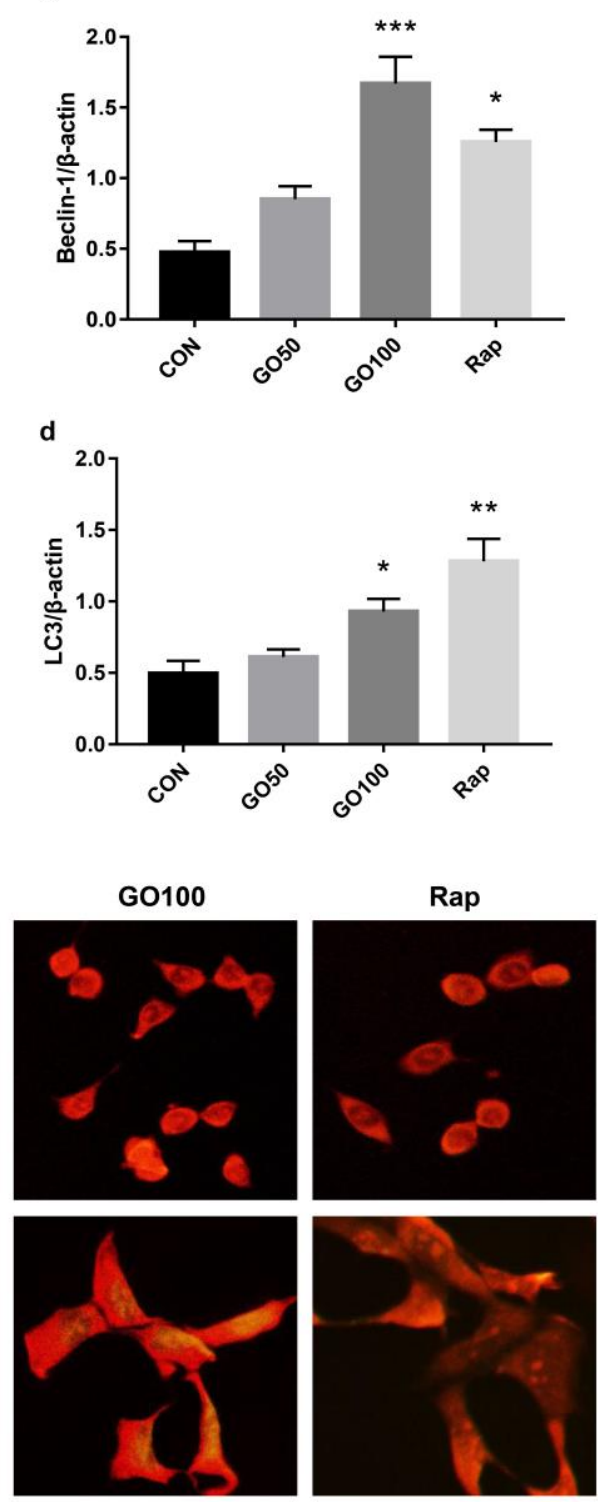
promoted microglia-mediated phagocytosis of Aß. (a) The representative immunoreactive bands of Beclin1 (60 kD), p62 (62 kD), LC3-I (16 kD), LC3-II (14 $\mathrm{kD}$ ), and $\beta$-actin (42 kD). SH-SY5Y cells were treated for $24 \mathrm{~h}$ with PBS (CON), 50 $\mu \mathrm{g} / \mathrm{ml} \mathrm{GO}$ (GO50), $100 \mu \mathrm{g} / \mathrm{ml} \mathrm{GO}$ (GO100) and rapamycin (Rap). (b) Quantitative analysis of Beclin- $1 / \beta$-actin in four groups. $\mathrm{n}=3$ /group, ${ }^{*} \mathrm{P}<0.05$, $* * * \mathrm{P}<0.001$ vs. CON group. (c) Quantitative analysis of $\mathrm{P} 62 / \beta$-actin in four groups $\mathrm{n}=3$ /group, ${ }^{* *} \mathrm{P}$ $<0.01, * * * \mathrm{P}<0.001$ vs. CON group. (d) Quantitative analysis of LC3-II/LC3-I in four groups. $\mathrm{n}=3$ /group, ${ }^{*} \mathrm{P}<0.05,{ }^{*} * \mathrm{P}<0.01$ vs. $\mathrm{CON}$ group. (e) Fluorescence microscopy of acridine orange-stained BV2 cells (row 1) and SH-SY5Y cells (row 2) treated for 24 h by GO in four groups. (scale bar: $20 \mu \mathrm{m}$ ). (f) CLSM measurements of BV2 cells treated with $\mathrm{A} \beta$-FITC, a mixture of $\mathrm{A} \beta$-FITC/GO50, $\mathrm{A} \beta$-FITC/GO100 and $\mathrm{A} \beta$ FITC/Rap. (scale bar: $20 \mu \mathrm{m}$ ). (g) Flow cytometry analysis of the average fluorescence intensity of $\mathrm{A} \beta$ in BV2 cells in the four groups. $\mathrm{n}=3$ /group, ${ }^{* *} \mathrm{P}<0.01 * * * \mathrm{P}<0.001$ vs. CON group.

\subsection{Graphene oxide protected neurons through promoting the clearance of $A \beta$ in pathological conditions under co-culture conditions}

The BV2 cells and SH-SY5Y cells were co-cultured in order to investigate whether GO has the ability of clearing $A \beta$ and protecting neurons through the improved autophagy under the pathological conditions. $A \beta$ was added to the medium to simulate a more realistic pathological environment. Under this culture condition, the growth status of the SH-SY5Y cells was monitored in real time with or without adding of GO. 
As shown in Fig. 4a, the density of neurons in the GO-added group was greater than that of the control group at $24 \mathrm{~h}, 36 \mathrm{~h}$ and $48 \mathrm{~h}$.

To understand the role of microglial and neurons in clearing A $\beta$ induced by GO, the content of autophagy-related protein LC3 under co-culture of two types of cells with GO were measured. The immunofluorescence results were shown in Fig.4b, both the BV2 cells and SH-SY5Y cells had a significant increase in LC3 content after GO treatment, which was similar to the results obtained from mono-cultures respectively. As shown in Fig.4c and Fig.4d, the contents of autophagy-related proteins were greater in the BV2 cells than those in the SH-SY5Y cells. More A $\beta$-carrying fluorescence was detected in both BV2 cells and SH-SY5Y cells with addition of GO, and the green fluorescence was slightly more in the BV2 cells than that of the SH-SY5Y cells, as shown in Fig. 4e and Fig.4f. 
a

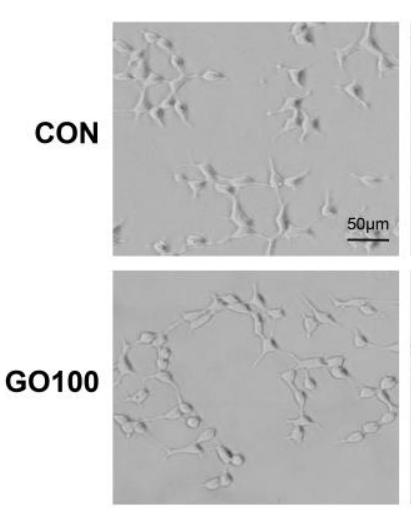

b

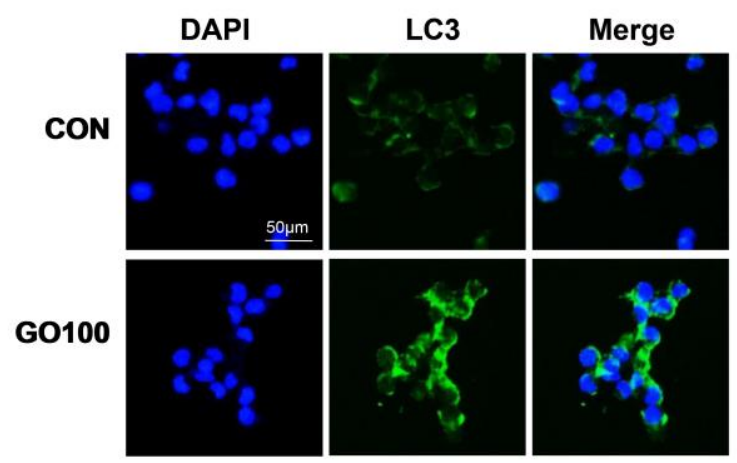

BV2
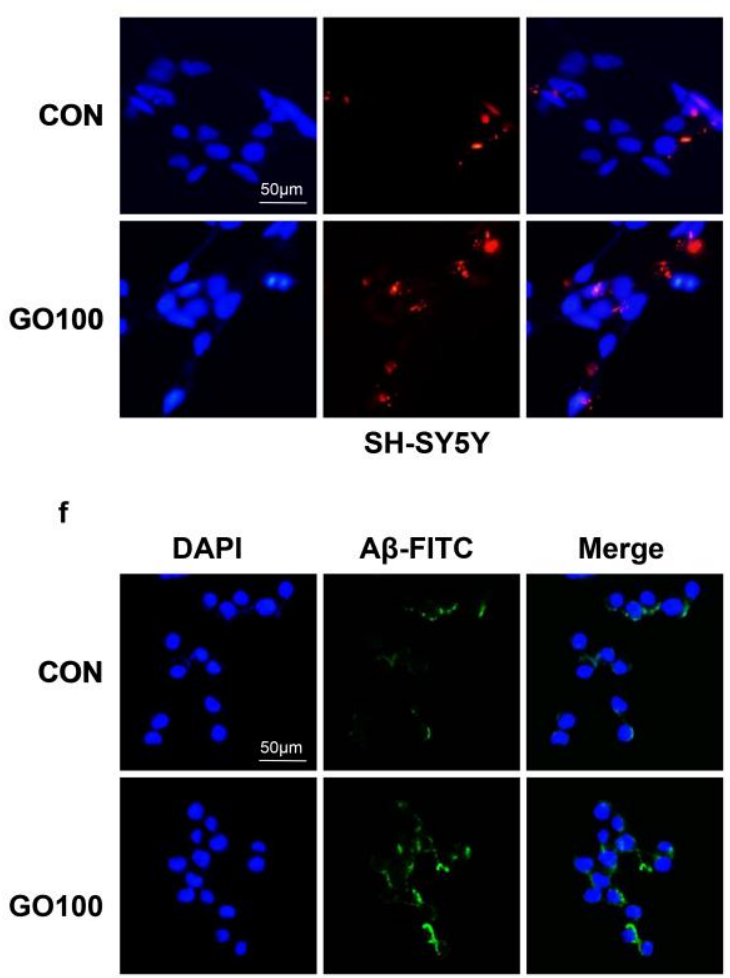

$24 \mathrm{~h}$
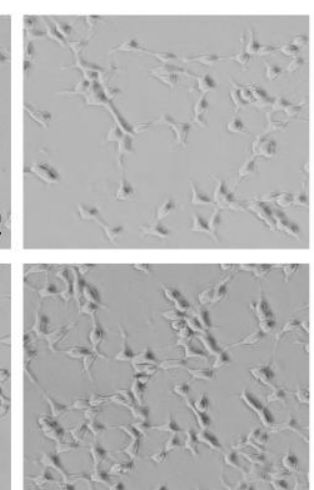

C
A $\beta-$ FITC
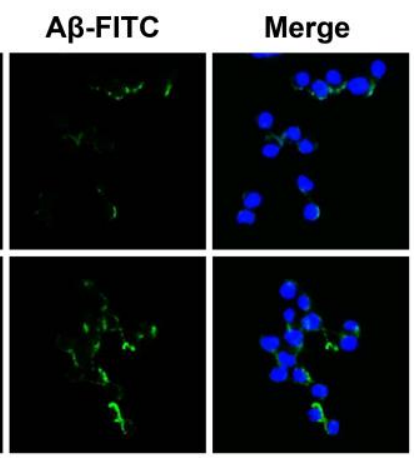

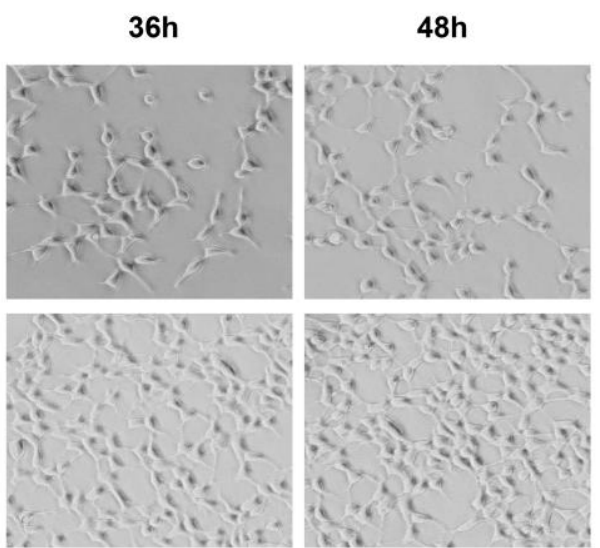

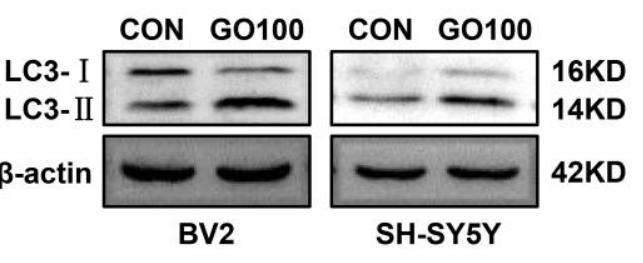

d

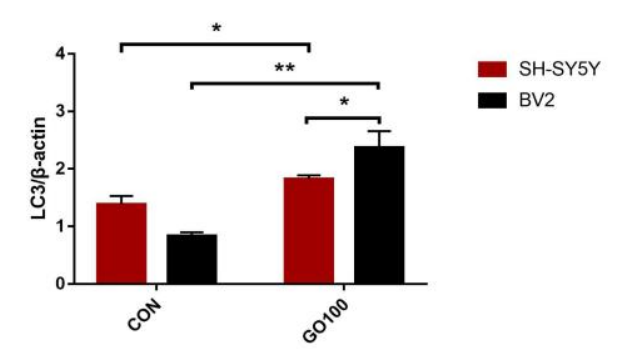

e

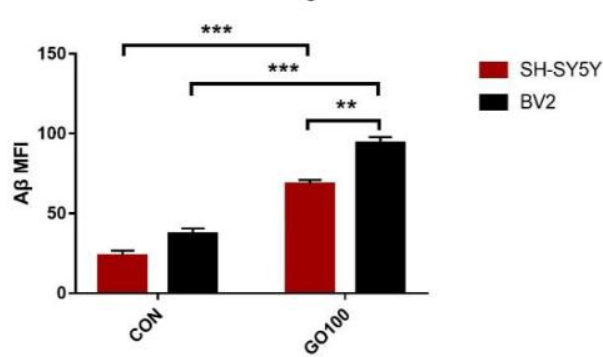

BV2

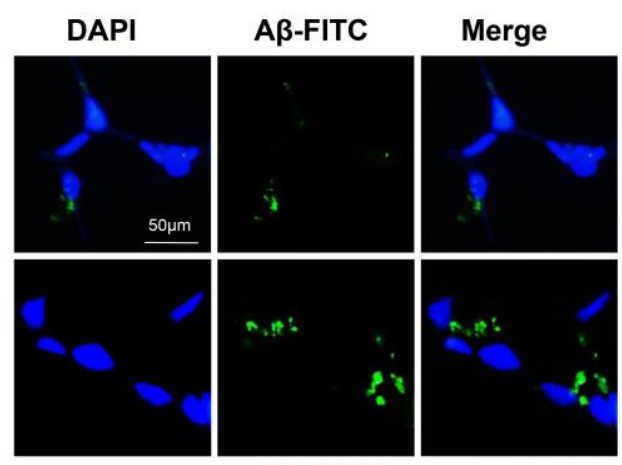

SH-SY5Y

Figure 4. The neuroprotective effect of GO and the effect of GO on the autophagy of BV2 cells and SH-SY5Y cells under co-culture. (a) The proliferation of SH-SY5Y 
cells in the CON group and GO100 (100 $\mu \mathrm{g} / \mathrm{ml} \mathrm{GO})$ group at 12h, 24h, 36h, and 48h. (scale bar: $20 \mu \mathrm{m}$ ). (b) The results of immunofluorescence of LC3 protein in two groups of BV2 cells and SH-SY5Y cells under co-culture. (scale bar: $20 \mu \mathrm{m}$ ). (c) The representative immunoreactive bands of LC3-I (16 kD), LC3-II (14 kD), and $\beta$-actin (42kD). BV2 cells and SH-SY5Y cells under co-culture were treated for $24 \mathrm{~h}$ with PBS $(\mathrm{CON})$ and $100 \mu \mathrm{g} / \mathrm{ml} \mathrm{GO}(\mathrm{GO} 100)$. (d) Quantitative analysis of LC3-II/LC3-I in BV2 cells and SH-SY5Y cells in two groups under co-culture. $\mathrm{n}=3$ /group, $* \mathrm{P}<0.05 * * \mathrm{P}$ $<0.01$ vs. CON group. (e) Flow cytometry analysis of the average fluorescence intensity of $\mathrm{A} \beta$ in BV2 cells and SH-SY5Y cells of four groups under co-culture. $n=3$ /group, $* * \mathrm{P}<0.01 * * * \mathrm{P}<0.001$ vs. CON group. (f) Fluorescence microscopy of BV2 cells and SH-SY5Y cells treated with A $\beta$-FITC and a mixture of A $\beta$-FITC/GO100. (scale bar: $50 \mu \mathrm{m})$.

\subsection{Graphene oxide induced autophagy through activating AMPK to inhibit mTOR signaling pathway}

In order to study how GO induced the autophagy in microglia and neurons, Western blot assay was used to examine upstream proteins. The expressions of AMPK and mTOR proteins were changed after treatment with GO. As shown in Fig. 5a-c, the phosphorylation of AMPK significantly increased and the phosphorylation of mTOR reduced in both microglial and neurons after the GO treatment. At the same time, the phosphorylation of AMPK and mTOR in the group treated with $100 \mu \mathrm{g} / \mathrm{ml} \mathrm{GO}$ was more significant changed. Therefore, compound $\mathrm{C}$, a specific inhibitor of AMPK, was 
used to treat cells. Compound $\mathrm{C}$ was used in the $100 \mu \mathrm{g} / \mathrm{ml} \mathrm{GO}$ group. The expressions of autophagy-related proteins were shown in Fig. 5d-i. Our results showed that the use of compound $\mathrm{C}$ indeed inhibited the phosphorylation of AMPK, thereby reducing the upregulation of LC3-II/LC3-I and Beclin-1 expression caused by GO $(100 \mu \mathrm{g} / \mathrm{ml})$. At the same time, the treatment with compound $\mathrm{C}$ also prevented the degradation of SQSTM1/p62 caused by GO $(100 \mu \mathrm{g} / \mathrm{ml})$.

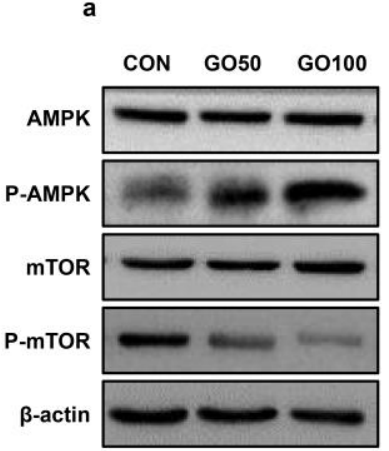

BV2

d CON GO100 $\begin{gathered}\mathrm{GO100+} \\ \text { compound C }\end{gathered}$ CON G0100 $\begin{gathered}\mathrm{GO100+} \\ \text { compound C }\end{gathered}$

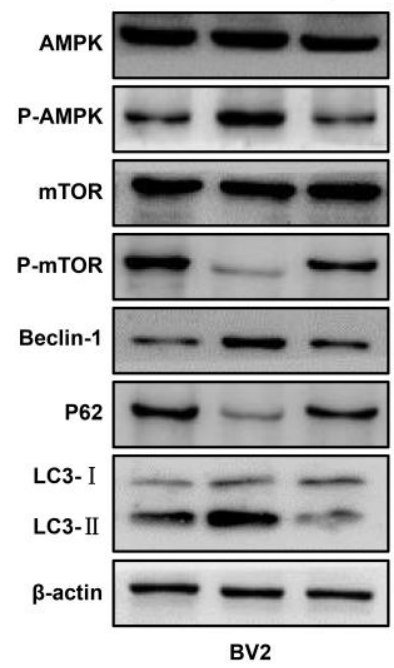

g

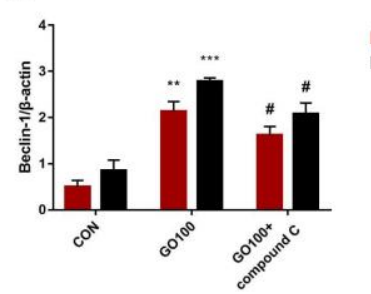

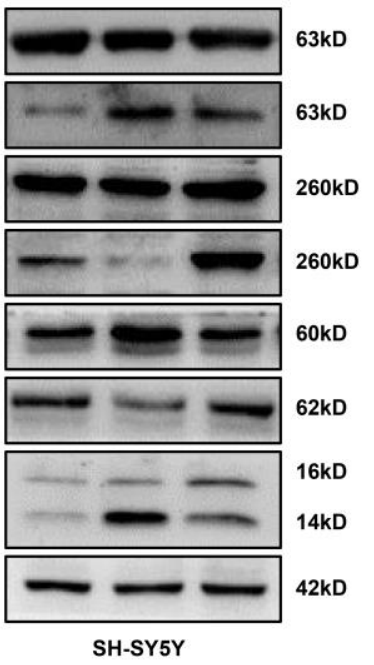

h - $\mathrm{SH}_{\mathrm{B} 2} \mathrm{SY} 5 \mathrm{Y}$

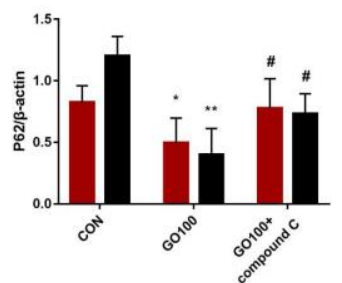

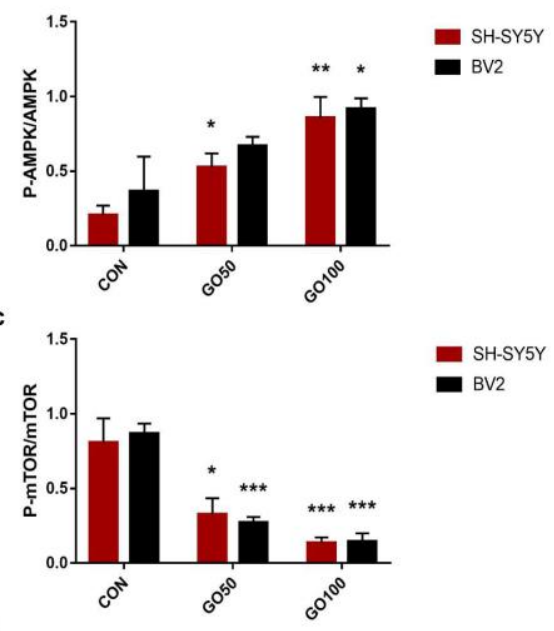

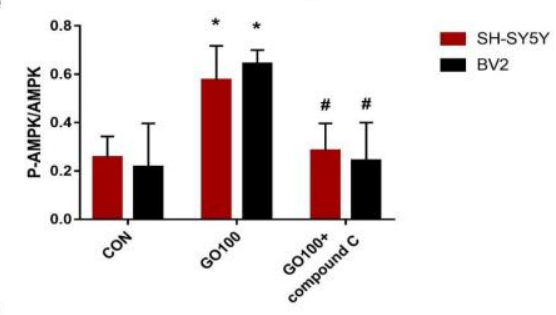

f
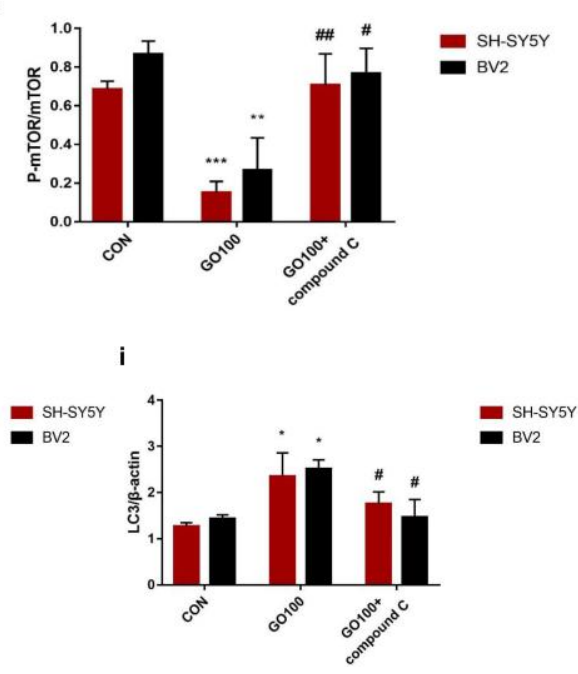
Figure 5 GO promoted the autophagy by activating AMPK to inhibit mTOR. (a) The representative immunoreactive bands of AMPK (63 kD), p-AMPK (63 kD), mTOR (260 kD), p-mTOR (260 kD), and $\beta$-actin (42 kD). BV2 cells and SH-SY5Y cells were treated for $24 \mathrm{~h}$ with PBS (CON), $50 \mu \mathrm{g} / \mathrm{ml} \mathrm{GO}(\mathrm{GO} 50)$ and $100 \mu \mathrm{g} / \mathrm{ml} \mathrm{GO}$ (GO100). (b) Quantitative analysis of $\mathrm{p}$-AMPK/AMPK in three groups. $\mathrm{n}=3$ /group, ${ }^{*} \mathrm{P}<0.05$, ** $\mathrm{P}<0.01$ vs. CON group. (c) Quantitative analysis of $\mathrm{p}-\mathrm{mTOR} / \mathrm{mTOR}$ in three groups. $\mathrm{n}=3$ /group, $* \mathrm{P}<0.05, * * * \mathrm{P}<0.001$ vs. CON group. (d) The representative immunoreactive bands of AMPK (63 kD), p-AMPK (63 kD), mTOR (260 kD), pmTOR (260 kD), Beclin-1 (60 kD), p62 (62 kD), LC3-I (16 kD), and LC3-II (14 kD) and $\beta$-actin (42kD). BV2 cells and SH-SY5Y cells were treated for $24 \mathrm{~h}$ with PBS (CON), $100 \mu \mathrm{g} / \mathrm{ml} \mathrm{GO}(\mathrm{GO} 50)$ and $100 \mu \mathrm{g} / \mathrm{ml} \mathrm{GO}(\mathrm{GO} 100)+$ compound $\mathrm{C}(10 \mu \mathrm{M})$. (e) Quantitative analysis of p-AMPK/AMPK in three groups, ${ }^{*} \mathrm{P}<0.05$ vs. CON group, \#P $<0.05$, vs. GO100 (100 $\mu \mathrm{g} / \mathrm{ml})$ group. (f) Quantitative analysis of $\mathrm{p}-\mathrm{mTOR} / \mathrm{mTOR}$ in three groups. $\mathrm{n}=3$ /group, $* * \mathrm{P}<0.01, * * * \mathrm{P}<0.001$ vs. $\mathrm{CON}$ group, \#P $<0.05$, \#\# $\mathrm{P}$ $<0.01$ vs GO100 $(100 \mu \mathrm{g} / \mathrm{ml})$ group. (g) Quantitative analysis of three groups of Beclin$1 / \beta$-actin. $\mathrm{n}=3 /$ group, $* * \mathrm{P}<0.01, * * * \mathrm{P}<0.001$ vs. $\mathrm{CON}$ group, $\# \mathrm{P}<0.05$ vs. GO100 (100 $\mu \mathrm{g} / \mathrm{ml}$ ) group. (h) Quantitative analysis of P62/ $\beta$-actin in three groups. $\mathrm{n}=3 /$ group, * $\mathrm{P}<0.05,{ }^{*} * \mathrm{P}<0.01$ vs. CON group, \#P $<0.05$ vs. GO100 (100 $\left.\mu \mathrm{g} / \mathrm{ml}\right)$ group. (i) Quantitative analysis of LC3-II/LC3-I in three groups. $\mathrm{n}=3$ /group, ${ }^{*} \mathrm{P}<0.05$, vs. CON group, \#P $<0.05$ vs. GO100 $(100 \mu \mathrm{g} / \mathrm{ml})$ group.

\section{Discussion}


The main purpose of this study was to investigate whether GO promoted the clearance of $A \beta$ by activating autophagy to treat Alzheimer's disease. Our results indicated that GO activated autophagy of both microglia and neurons through the $\mathrm{AMPK} / \mathrm{mTOR}$ pathway to promote $\mathrm{A} \beta$ clearance and protect neurons.

A strategy of activating autophagy of microglia or neurons is effective in treating $\mathrm{AD}[41,43-45]$, and studies showed that the activating autophagy flux promoted the clearance of $\mathrm{A} \beta[46,47]$. Recent research showed that GO played an important role in cell proliferation, anti-tumor effects, and anti-oxidation [29, 48]. Jeong et al. found that GO treatment prevented PrP (106-126) -mediated neurotoxicity [29]. This underlines the tremendous capabilities of GO in the biomedical field. In particular, GO induced autophagy flux in certain cells and tissues [49-51]. Jin et al. showed that GO enhanced the clearance of Htt protein in GFP-Htt (Q74)/PC12 cells [52], thus suggesting that GO was of great potential for treating neurodegenerative diseases.

In this study, we investigated the effect of GO on the autophagy flux in microglia and neurons. The results showed that GO effectively increased the content of autophagy-related protein Beclin-1 and reduced the content of P62 in the BV2 cells and SH-SY5Y cells, and increased the ratio of LC3-II to LC3-I. Changes in these autophagy-related proteins demonstrated that the autophagy was up-regulated [36]. The acidic autophagosomes and acid lysosomes also increased significantly in the GO treatment groups. With the increase of the autophagy ability of both BV2 cells and SHSY5Y cells, the ability of $A \beta$ clearance was significantly increased. It was worth mentioning that the effect of GO on the BV2 was more obvious (Fig.4d, e). A possible 
reason may be that GO significantly improved the phagocytic ability of the BV2 cells (Fig.3f, g). After A $\beta$ was produced, it was recycled to the cell surface and aggregated outside the cell while the autophagic degradation occurred intracellularly [41]. Therefore, improving the phagocytic ability of the BV2 cells was the prerequisite for improving $A \beta$ degradation by autophagy-lysosomal pathway. Another reason may be that GO had a greater effect on the autophagy flux of the BV2 cells (Fig.4c, d), and was able to improve the $A \beta$ clearance efficiency in the process of $A \beta$ degradation by autophagy-lysosomal pathway.

As the data demonstrated that GO up-regulated the autophagy in the BV2 cells and SH-SY5Y cells, we focused on the reasons why GO induced the autophagy. Our results showed that AMPK and mTOR were involved in this process (Fig.5a-c). Previous studies suggested that autophagy is promoted by AMPK and inhibited by the mTOR $[53,54]$. To understand the mechanism of the autophagy induced by GO, compound C, an inhibitor of AMPK, affected the upstream and downstream relationship between these two proteins. Our results (Fig.5f) indicated that the inhibition of AMPK by compound $\mathrm{C}$ induced mTOR activation and then reduced autophagy levels corresponding to the current research findings [20, 54]. As GO showed an inhibitory effect on mTOR proteins, the autophagy activator, rapamycin, was used in the experiment to activate autophagy. Our results (Fig.2, 3) demonstrated that the GOactivated autophagy was comparable to rapamycin-activated autophagy. This suggests that GO has the potential to become an autophagy activator.

A co-culturing model of BV2 cells and SH-SY5Y cells was adopted in our study 
to simulate the more realistic pathological environment of AD [38]. We demonstrated that GO was able to increase the autophagy capacity of both cells under co-culture conditions and promoted the clearance of $\mathrm{A} \beta$, similar to the results of mono-cultures of the two types of cells respectively, which suggested that GO could be a good neurons protector (Fig.4a). Importantly, the MTT results found that GO itself was not toxic to microglia and neurons (Fig.1c, d). Moreover, the size of GO nanosheets met the size requirement to cross the $\mathrm{BBB}$, thus increased their potential to be a drug delivery carrier.

To the best of our knowledge, this is the first study of GO in the treatment of Alzheimer's disease. We explored the toxicity of GO to cells, the ability of GO to induce autophagy, the effect of GO in promoting $\mathrm{A} \beta$ clearance and the neuroprotective effect of GO. Our results demonstrated that GO had an ability to activate autophagy and clear $\mathrm{A} \beta$, and showed a good neuroprotective effect, which indicates that GO had a great potential for the treatment of $\mathrm{AD}$. The new biological functions of GO in $\mathrm{A} \beta$ clearance revealed from our study may be of great significance for the development of nanomaterial-based treatments for neurodegenerative diseases.

\section{Conclusions}

In summary, we have demonstrated the novel biological activity of GO in accelerating $A \beta$ protein clearance, which is achieved through enhancing autophagy levels. We have found that GO can inhibit mTOR-induced autophagy flux by activating AMPK, and has a good neuroprotective effect. Our observations provide a new theoretical basis for the treatment of Alzheimer's disease and other neurodegenerative diseases. 


\section{Acknowledgments}

This work was supported by the National Natural Science Foundation of China (81771979), and the Applied Basic Research Programs of Science and Technology Commission Foundation of Tianjin (18JCYBJC27400). The support from the Royal Society (UK) for International Exchanges (IECINSFC1181045) is gratefully acknowledged.

\section{References}

[1] LaFerla FM, Oddo S. Alzheimer's disease: Abeta, tau and synaptic dysfunction. Trends in molecular medicine 2005;11:170-6.

[2] Xin SH, Tan L, Cao X, Yu JT, Tan L. Clearance of Amyloid Beta and Tau in Alzheimer's Disease: from Mechanisms to Therapy. Neurotoxicity research 2018;34:733-48.

[3] Selkoe DJ. Alzheimer's disease: genes, proteins, and therapy. Physiol Rev 2001;81:741-66.

[4] Tanokashira D, Mamada N, Yamamoto F, Taniguchi K, Tamaoka A, Lakshmana MK, et al. The neurotoxicity of amyloid beta-protein oligomers is reversible in a primary neuron model. 2017;10:4.

[5] Ziegler-Waldkirch S, d'Errico P, Sauer JF, Erny D, Savanthrapadian S, Loreth D, et al. Seed-induced Abeta deposition is modulated by microglia under environmental enrichment in a mouse model of Alzheimer's disease. 2018;37:167-82. 
[6] Ramirez AI, de Hoz R, Salobrar-Garcia E, Salazar JJ, Rojas B, Ajoy D, et al. The Role of Microglia in Retinal Neurodegeneration: Alzheimer's Disease, Parkinson, and Glaucoma. Frontiers in aging neuroscience 2017;9:214.

[7] Leinenga G, Gotz J. Scanning ultrasound removes amyloid-beta and restores memory in an Alzheimer's disease mouse model. Science translational medicine 2015;7:278ra33.

[8] Zuroff L, Daley D, Black KL, Koronyo-Hamaoui M. Clearance of cerebral Abeta in Alzheimer's disease: reassessing the role of microglia and monocytes. 2017;74:2167-201.

[9] Mawuenyega KG, Sigurdson W, Ovod V, Munsell L, Kasten T, Morris JC, et al. Decreased clearance of CNS beta-amyloid in Alzheimer's disease. Science 2010;330:1774.

[10] Honig LS, Vellas B, Woodward M, Boada M, Bullock R, Borrie M, et al. Trial of Solanezumab for Mild Dementia Due to Alzheimer's Disease. N Engl J Med 2018;378:321-30.

[11] Rygiel K. Novel strategies for Alzheimer's disease treatment: An overview of antiamyloid beta monoclonal antibodies. Indian J Pharmacol 2016;48:629-36.

[12] Gonzalez-Marrero I, Gimenez-Llort L, Johanson CE, Carmona-Calero EM, Castaneyra-Ruiz L, Brito-Armas JM, et al. Choroid plexus dysfunction impairs betaamyloid clearance in a triple transgenic mouse model of Alzheimer's disease. Front Cell Neurosci 2015;9:17.

[13] Zuroff L, Daley D, Black KL, Koronyo-Hamaoui M. Clearance of cerebral Abeta 
in Alzheimer's disease: reassessing the role of microglia and monocytes. Cell Mol Life Sci 2017;74:2167-201.

[14] Nixon RA. Autophagy, amyloidogenesis and Alzheimer disease. Journal of cell science $2007 ; 120: 4081-91$.

[15] Cai Z, Zhao B, Li K, Zhang L, Li C, Quazi SH, et al. Mammalian target of rapamycin: a valid therapeutic target through the autophagy pathway for Alzheimer's disease? J Neurosci Res 2012;90:1105-18.

[16] Wani A, Gupta M, Ahmad M, Shah AM, Ahsan AU, Qazi PH, et al. Alborixin clears amyloid-beta by inducing autophagy through PTEN-mediated inhibition of the AKT pathway. Autophagy 2019;15:1810-28.

[17] Nixon RA. Amyloid precursor protein and endosomal-lysosomal dysfunction in Alzheimer's disease: inseparable partners in a multifactorial disease. FASEB journal : official publication of the Federation of American Societies for Experimental Biology 2017;31:2729-43.

[18] Nixon RA. The role of autophagy in neurodegenerative disease. Nat Med 2013;19:983-97.

[19] Maiese K. Targeting molecules to medicine with mTOR, autophagy and neurodegenerative disorders. British journal of clinical pharmacology 2016;82:124566.

[20] Wen Z, Zhang J, Tang P, Tu N, Wang K, Wu G. Overexpression of miR185 inhibits autophagy and apoptosis of dopaminergic neurons by regulating the AMPK/mTOR signaling pathway in Parkinson's disease. Molecular medicine reports 2018;17:131-7. 
[21] Prabakaran T, Bodda C, Krapp C, Zhang BC, Christensen MH, Sun C, et al. Attenuation of cGAS-STING signaling is mediated by a p62/SQSTM1-dependent autophagy pathway activated by TBK1. 2018;37.

[22] Rubinsztein DC, Cuervo AM, Ravikumar B, Sarkar S, Korolchuk V, Kaushik S, et al. In search of an "autophagomometer". Autophagy 2009;5:585-9.

[23] Xu HD, Qin ZH. Beclin 1, Bcl-2 and Autophagy. Advances in experimental medicine and biology 2019;1206:109-26.

[24] Zheng W, Wei M, Li S, Le W. Nanomaterial-modulated autophagy: underlying mechanisms and functional consequences. Nanomedicine (London, England) 2016;11:1417-30.

[25] Raju GSR, Pavitra E, Merchant N, Lee H, Prasad GLV, Nagaraju GP, et al. Targeting autophagy in gastrointestinal malignancy by using nanomaterials as drug delivery systems. Cancer letters 2018;419:222-32.

[26] Wei M, Le WD. The Role of Nanomaterials in Autophagy. Advances in experimental medicine and biology 2019;1206:273-86.

[27] Singh DP, Herrera CE, Singh B, Singh S, Singh RK, Kumar R. Graphene oxide: An efficient material and recent approach for biotechnological and biomedical applications. Mater Sci Eng C Mater Biol Appl 2018;86:173-97.

[28] Chen GY, Pang DW, Hwang SM, Tuan HY, Hu YC. A graphene-based platform for induced pluripotent stem cells culture and differentiation. Biomaterials 2012;33:418-27.

[29] Jeong JK, Lee YJ, Jeong SY, Jeong S, Lee GW, Park SY. Autophagic flux induced 
by graphene oxide has a neuroprotective effect against human prion protein fragments. International journal of nanomedicine 2017;12:8143-58.

[30] Zheng XT, Li CM. Restoring basal planes of graphene oxides for highly efficient loading and delivery of beta-lapachone. Molecular pharmaceutics 2012;9:615-21.

[31] Wan B, Wang ZX, Lv QY, Dong PX, Zhao LX, Yang Y, et al. Single-walled carbon nanotubes and graphene oxides induce autophagosome accumulation and lysosome impairment in primarily cultured murine peritoneal macrophages. Toxicology letters 2013;221:118-27.

[32] Ou L, Lin S, Song B, Liu J, Lai R, Shao L. The mechanisms of graphene-based materials-induced programmed cell death: a review of apoptosis, autophagy, and programmed necrosis. International journal of nanomedicine 2017;12:6633-46.

[33] Qin Y, Zhou ZW, Pan ST, He ZX, Zhang X, Qiu JX, et al. Graphene quantum dots induce apoptosis, autophagy, and inflammatory response via p38 mitogen-activated protein kinase and nuclear factor-kappaB mediated signaling pathways in activated THP-1 macrophages. Toxicology 2015;327:62-76.

[34] Tomic S, Janjetovic K, Mihajlovic D, Milenkovic M, Kravic-Stevovic T, Markovic $\mathrm{Z}$, et al. Graphene quantum dots suppress proinflammatory $\mathrm{T}$ cell responses via autophagy-dependent induction of tolerogenic dendritic cells. Biomaterials 2017;146:13-28.

[35] Shan M, Qin J, Jin F, Han X, Guan H, Li X, et al. Autophagy suppresses isoprenaline-induced M2 macrophage polarization via the ROS/ERK and mTOR signaling pathway. Free radical biology \& medicine 2017;110:432-43. 
[36] Zhang X, Yin H, Li Z, Zhang T, Yang Z. Nano-TiO2 induces autophagy to protect against cell death through antioxidative mechanism in podocytes. Cell biology and toxicology 2016;32:513-27.

[37] Kunzler A, Zeidán-Chuliá F, Gasparotto J, Girardi CS, Klafke K, Petiz LL, et al. Changes in Cell Cycle and Up-Regulation of Neuronal Markers During SH-SY5Y Neurodifferentiation by Retinoic Acid are Mediated by Reactive Species Production and Oxidative Stress. Molecular neurobiology 2017;54:6903-16.

[38] Sun XD, Li L, Liu F, Huang ZH, Bean JC, Jiao HF, et al. Lrp4 in astrocytes modulates glutamatergic transmission. Nature neuroscience 2016;19:1010-8.

[39] Li K, Li W, Yin H, Cheong YK, Ren G, Yang Z. Pretreatment-Etidronate Alleviates CoCl2 Induced-SH-SY5Y Cell Apoptosis via Decreased HIF-1alpha and TRPC5 Channel Proteins. Neurochemical research 2019;44:428-40.

[40] Gao N, Wang H, Yin H, Yang Z. Angiotensin II induces calcium-mediated autophagy in podocytes through enhancing reactive oxygen species levels. Chem Biol Interact 2017;277:110-8.

[41] Luo Q, Lin YX, Yang PP, Wang Y, Qi GB, Qiao ZY, et al. A self-destructive nanosweeper that captures and clears amyloid beta-peptides. Nature communications 2018;9:1802.

[42] Zhao Y, Cai J, Liu Z, Li Y, Zheng C, Zheng Y, et al. Nanocomposites Inhibit the Formation, Mitigate the Neurotoxicity, and Facilitate the Removal of beta-Amyloid Aggregates in Alzheimer's Disease Mice. Nano letters 2019;19:674-83.

[43] Xu Z, Nan W, Zhang X, Sun Y, Yang J, Lu K, et al. Umbilical Cord Mesenchymal 
Stem Cells Conditioned Medium Promotes Abeta25-35 phagocytosis by Modulating Autophagy and Abeta-Degrading Enzymes in BV2 Cells. Journal of molecular neuroscience : MN 2018;65:222-33.

[44] Cho MH, Cho K, Kang HJ, Jeon EY, Kim HS, Kwon HJ, et al. Autophagy in microglia degrades extracellular beta-amyloid fibrils and regulates the NLRP3 inflammasome. Autophagy 2014;10:1761-75.

[45] Han K, Jia N, Zhong Y, Shang X. S14G-humanin alleviates insulin resistance and increases autophagy in neurons of APP/PS1 transgenic mouse. 2018;119:3111-7.

[46] Wei Y, Zhou J, Wu J, Huang J. ERbeta promotes Abeta degradation via the modulation of autophagy. Cell death \& disease 2019;10:565.

[47] Wan Y, Liang Y, Liang F, Shen N, Shinozuka K, Yu JT, et al. A Curcumin Analog Reduces Levels of the Alzheimer's Disease-Associated Amyloid-beta Protein by Modulating AbetaPP Processing and Autophagy. Journal of Alzheimer's disease : JAD 2019;72:761-71.

[48] Chen GY, Meng CL, Lin KC, Tuan HY, Yang HJ, Chen CL, et al. Graphene oxide as a chemosensitizer: diverted autophagic flux, enhanced nuclear import, elevated necrosis and improved antitumor effects. Biomaterials 2015;40:12-22.

[49] Chen GY, Yang HJ, Lu CH, Chao YC, Hwang SM, Chen CL, et al. Simultaneous induction of autophagy and toll-like receptor signaling pathways by graphene oxide. Biomaterials 2012;33:6559-69.

[50] Chen GY, Chen CL, Tuan HY, Yuan PX, Li KC, Yang HJ, et al. Graphene oxide triggers toll-like receptors/autophagy responses in vitro and inhibits tumor growth in 
vivo. Advanced healthcare materials 2014;3:1486-95.

[51] Mari E, Mardente S, Morgante E, Tafani M, Lococo E, Fico F, et al. Graphene Oxide Nanoribbons Induce Autophagic Vacuoles in Neuroblastoma Cell Lines. International journal of molecular sciences 2016;17.

[52] Jin P, Wei P, Zhang Y, Lin J, Sha R, Hu Y, et al. Autophagy-mediated clearance of ubiquitinated mutant huntingtin by graphene oxide. Nanoscale 2016;8:18740-50.

[53] Heras-Sandoval D, Perez-Rojas JM, Pedraza-Chaverri J. Novel compounds for the modulation of mTOR and autophagy to treat neurodegenerative diseases. Cellular signalling 2020;65:109442.

[54] Shan SR, Jiang F, Xu SM. [Effects of H102 on the memory recognition ability and AMPK-mTOR autophagy-related pathway in AD mice]. Zhongguo ying yong sheng li xue za zhi $=$ Zhongguo yingyong shenglixue zazhi $=$ Chinese journal of applied physiology 2019;35:1-4. 